\title{
Mycobacteria in nerve trunks of long-term treated leprosy patients
}

\author{
J H PEREIRA*, D D PALANDE $\dagger \&$ \\ S E GSCHMEISSNER \\ * Department of Anatomy, Royal College of Surgeons of England \\ and Queen Victoria Hospital, East Grinstead, England; †Sacred \\ Heart Leprosy Centre, Saddukotai, Kumbakonam, Tamil Nadu, \\ South India; and $\ddagger$ Imperial Cancer Research Fund Electron Micro- \\ scopic Unit, Royal College of Surgeons of England, Lincoln's Inn, \\ London
}

\begin{abstract}
Accepted for publication 20 December 1990
Summary Mycobacteria were present in 4 out of 8 mixed peripheral nerve trunks from patients (3 BT and $1 \mathrm{BL}$ ) treated with DDS and/or MDT for periods ranging from 21 months to 8 years. Most of the bacilli appeared to be 'whole'. Nerve destruction with areas of granulomatous infiltration appeared more active than expected. Possible reasons for a continued presence of bacilli in treated nerves and its implications in 'relapse' are discussed.
\end{abstract}

\section{Introduction}

Mycobacterium leprae has a predilection for peripheral nerves and skin and is a major cause of peripheral neuropathy worldwide. ${ }^{1}$ Nerve histopathology in leprosy has been in general limited to cutaneous nerves. Sporadic studies on nerve trunks have appeared in the literature, but with the exception of one case ${ }^{2}$ this has been limited to untreated patients. We have been able to obtain segments of nerve trunks of leprosy patients on long-term drug treatment, during the course of a new operative treatment for localized nerve damage in leprosy (to be reported shortly). In half the operated cases histological studies have subsequently demonstrated the presence of intraneural $M$. leprae. The clinical history, histopathological findings and the possible role in relapse are discussed.

\section{Materials and methods}

PATIENTS

Eight patients, 5 males and 3 females, aged from 15 to 35 underwent operations on 3 median nerves at the wrist and 7 posterior tibial nerves at the ankle, at the Sacred Heart 
Table 1

\begin{tabular}{|c|c|c|c|c|c|c|c|c|c|c|c|c|}
\hline \multirow{2}{*}{\multicolumn{2}{|c|}{$\begin{array}{l}\text { Case no. } \\
\text { and } \\
\text { initials }\end{array}$}} & \multirow{2}{*}{$\begin{array}{l}\text { Age/ } \\
\text { sex }\end{array}$} & \multirow{2}{*}{$\begin{array}{c}\text { Type } \\
\text { of } \\
\text { disease }\end{array}$} & \multirow{2}{*}{$\begin{array}{c}\text { Duration } \\
\text { of } \\
\text { disease }\end{array}$} & \multirow{2}{*}{$\begin{array}{l}\text { Drug } \\
\mathrm{Rx}\end{array}$} & \multirow{2}{*}{$\begin{array}{c}\text { Presenting } \\
\text { nerve }\end{array}$} & \multirow{2}{*}{$\begin{array}{c}\text { Other } \\
\text { nerves } \\
\text { involved }\end{array}$} & \multirow{2}{*}{$\begin{array}{c}\mathrm{H} / \mathrm{O} \\
\text { neuritis }\end{array}$} & \multirow{2}{*}{$\begin{array}{c}\text { Skin-smear } \\
\text { test }\end{array}$} & \multirow[b]{2}{*}{ PMH } & \multicolumn{2}{|c|}{ Examination of presenting nerve } \\
\hline & & & & & & & & & & & Motor & Sensory \\
\hline 1 & RG & $32 / \mathrm{M}$ & BT & $11 \mathrm{yr}$ & $\begin{array}{l}\text { DDS } \\
8 \mathrm{yr}\end{array}$ & $\begin{array}{l}\text { (R) PT } \\
4 \mathrm{yr}\end{array}$ & $\begin{array}{l}\text { (L) PT } \\
\text { Bilat. ulnar }\end{array}$ & $\begin{array}{l}\text { Bilat. ulnar } \\
\text { neuritis. } \\
\text { Thickened PT }\end{array}$ & Neg. & $\begin{array}{l}\text { Tendon } \\
\text { transfer op } \\
\text { (L) hand }\end{array}$ & $\begin{array}{l}\text { Complete loss } \\
\text { PT lesion }\end{array}$ & $\begin{array}{l}\text { Complete loss } \\
\text { over sole } \\
\text { of foot }\end{array}$ \\
\hline 2 & DP & $27 / \mathrm{F}$ & BT & $7 \mathrm{yr}$ & $\begin{array}{l}\text { MDT } \\
1 \mathrm{yr} 9 \mathrm{mth}\end{array}$ & $\begin{array}{l}(\mathrm{R}) \\
\text { median } \\
1 \frac{1}{2} \mathrm{yr}\end{array}$ & $\begin{array}{l}\text { Bilat. ulnar } \\
\text { median lesion }\end{array}$ & $\begin{array}{l}\text { Bilat. ulnar } \\
\text { median neuritis. } \\
\text { Bilaterally } \\
\text { thickened } \\
\text { median nerve }\end{array}$ & Pos. & - & $\begin{array}{l}\text { Complete low } \\
\text { median lesion. } \\
\text { Mobile clawing } \\
\text { ulnar lesions }\end{array}$ & $\begin{array}{l}\text { Complete median } \\
\text { sensory pralysis. } \\
\text { Partial ulnar lesion }\end{array}$ \\
\hline 3 & SV & $27 / \mathrm{M}$ & BT & $8 \mathrm{yr}$ & $\begin{array}{l}\text { DDS } \\
8 \mathrm{yr}\end{array}$ & $\begin{array}{l}\text { Bilat PT } \\
2 \mathrm{yr}\end{array}$ & - & $\begin{array}{l}\text { Bilat. ulnar } \\
\text { neuritis. } \\
\text { Bilaterally } \\
\text { thickened PT }\end{array}$ & Neg. & $\begin{array}{l}\text { Tendon } \\
\text { transf er op. } \\
\text { (L) hand }\end{array}$ & $\begin{array}{l}\text { Bilat. complete } \\
\text { paralysis due to } \\
\text { PT lesion }\end{array}$ & $\begin{array}{l}\text { Complete loss of } \\
\text { sole sensation } \\
\text { (bilaterial) }\end{array}$ \\
\hline 4 & $\mathrm{NJ}$ & $22 / \mathrm{M}$ & BL & $4 \frac{1}{2} \mathrm{yr}$ & $\begin{array}{l}\text { DDS } \\
4 \mathrm{yr} \\
\text { MDT } \\
6 / 12 \mathrm{mth}\end{array}$ & $\begin{array}{l}\text { (R) PT } \\
4 \mathrm{yr}\end{array}$ & $\begin{array}{l}\text { Bilat. } \\
\text { PT }\end{array}$ & $\begin{array}{l}\text { (R) PT } \\
\text { thickened }\end{array}$ & Neg. & $\begin{array}{l}\text { Bilat. PT } \\
\text { Decompression }\end{array}$ & $\begin{array}{l}\text { Complete paralysis } \\
\text { bilateral PT }\end{array}$ & $\begin{array}{l}\text { Complete loss over } \\
\text { sole (bilateral) }\end{array}$ \\
\hline
\end{tabular}


Leprosy Centre, Kumbakonam, South India in 1989. Five patients were borderlinetuberculoid (BT) cases and the rest belonged to the lepromatous end of the spectrum (1 BL and $2 \mathrm{LL}$ ). Operative procedures were carried out under axillary block or spinal anaesthesia and nerve lengths removed ranged from 2 to $5 \mathrm{~cm}$. All patients had established irreversible motor and sensory damage ranging from 18 months to 7 years and were on antileprosy drugs for 1-8 years. Steroid therapy and active trophic ulcerations were considered contraindications to operation.

Clinical details of four patients with bacilli in their nerves are given in Table 1.

\section{PROCESSING OF NERVES}

Segments of nerve were taken with a sharp blade and fixed in $2.5 \%$ buffered glutaraldehyde for $1 \mathrm{hr}$. They were then trimmed and cut to give approximately $1-\mathrm{mm}$ transverse sections and left in buffered glutaraldehyde for a further hour before transfer to a holding buffer. Once the specimens were brought back to our laboratory at the Royal College of Surgeons (with delays of 15-30 days), they were fixed in 1\% cacodylate buffered osmium tetroxide, the tissues were then washed in $70 \%$ ethanol, dehydrated through graded ethanols and embedded in Araldite. One micron, transverse sections were cut on a Reichart Jung OMU 111 ultramicrotome and stained with $1 \%$ toluidine blue in $1 \%$ sodium tetraborate selected. Ultrathin sections were cut at $70-90 \mathrm{~nm}$ and stained with saturated uranyl citrate in methanol and then Reynold's lead citrate. Sections were examined and photographed in a Zeiss 10B transmission electron microscope.

Nerve specimens were also fixed in buffered formaldehyde and paraffin embedded sections were made and stained with haematoxylin-eosin and a routine FF method was used to identify acid-fast bacilli.

\section{Results}

Results given below pertain to the 4 cases with bacilli in their nerves. However, a few relevant points with illustrations will be made on treated cases without evidence of intraneural bacilli.

\section{INTRAOPERATIVE FINDINGS}

Induration and inflammation of the flexor retinaculum and subcutaneous tissue was present in all cases, these changes being more pronounced with posterior tibial lesions where the retinaculum was found stretched over the thickened neurovascular bundle. On opening the flexor retinaculum of the ankle, the posterior tibial nerve was found to be swollen and inflamed and the epineurium was thickened. The nerve was closely adherent to the posterior tibial vessels, causing some compression but not occlusion of the lumen. In contrast the changes in the median nerve did not extend into the carpal tunnel. All three BT cases demonstrated localized fusiform nerve swelling, while the BL cases showed moderate generalized thickening. The nerves at deeper and more proximal levels showed the same degree of inflammation. The transected nerve ends generally showed pinkish neural tissue in separately identifiable fascicles, with the exception of one scarred distal 
stump (BL case). Nerve stumps appeared highly vascular in comparison to transected ends of normal nerves.

\section{LIGHT MICROSCOPY}

General histopathological findings are reported and the differences between tuberculoid and lepromatous nerve indicated by the type of granulomatous changes. Haematoxylineosin stained sections showed extensive nerve fibre destruction with varying degrees of lymphocytic and mononuclear cellular infiltration and fibrosis. Granular acid-fast bacilli were seen in 2 nerve sections (Case Nos 2 and 3).

Epineurial changes included thickening with large amounts of dense connective tissue and mononuclear cell infiltration with occasional granuloma formation. The perineurium appeared multilayered and thickened probably due to increased connective tissue (Figures 1 and 3). In some areas there was complete loss of normal perineurial architecture. Subperineurial infiltration with mononuclear cells was common (Figure 1), with patchy changes occurring in the perineurium. In addition to the above changes, foamy macrophages (Figure 3) were seen in the BL case.

A remarkable feature was the varying intrafascicular damage which involved a part of a fascicle, single or many fascicles. Myelinated axon destruction ranged from complete (Figure 3) to minimal loss (Figure 5), with little or great amounts of endoneurial fibrosis and mononuclear infiltration. Larger myelinated fibre size and numbers were noted in lepromatous cases (Figure 5). Bacilli were visualized as darkly stained spherical (sometimes elongated) structures within Schwann cells, and in the BL case many such structures were seen in foamy macrophages. Large numbers of vacuolated Schwann cells (Figure 1) were evident, surrounded by collagen and mononuclear cells.

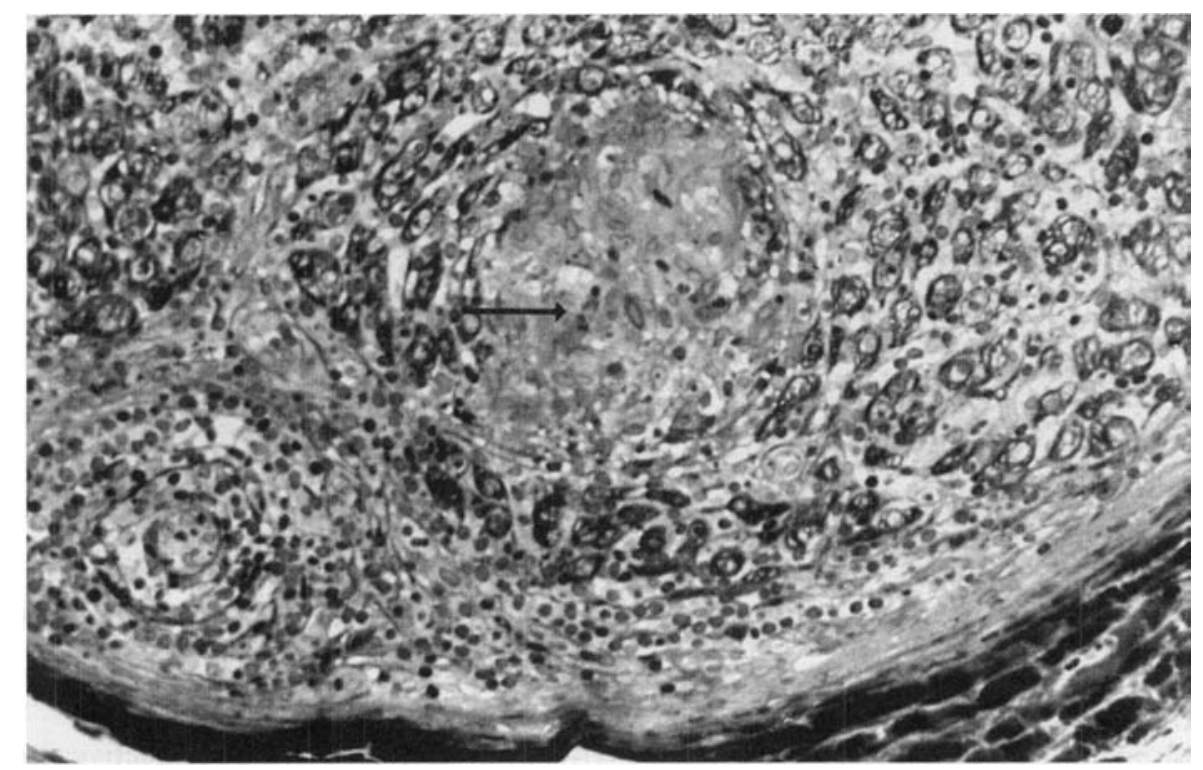

Figure 1. Median nerve of treated BT case showing multi-layered perinerium, subperineurial inflammatory cell infiltration, area of granuloma formation (arrow) and vacuolated Schwann cells. Toluidine blue $\times 275$. 


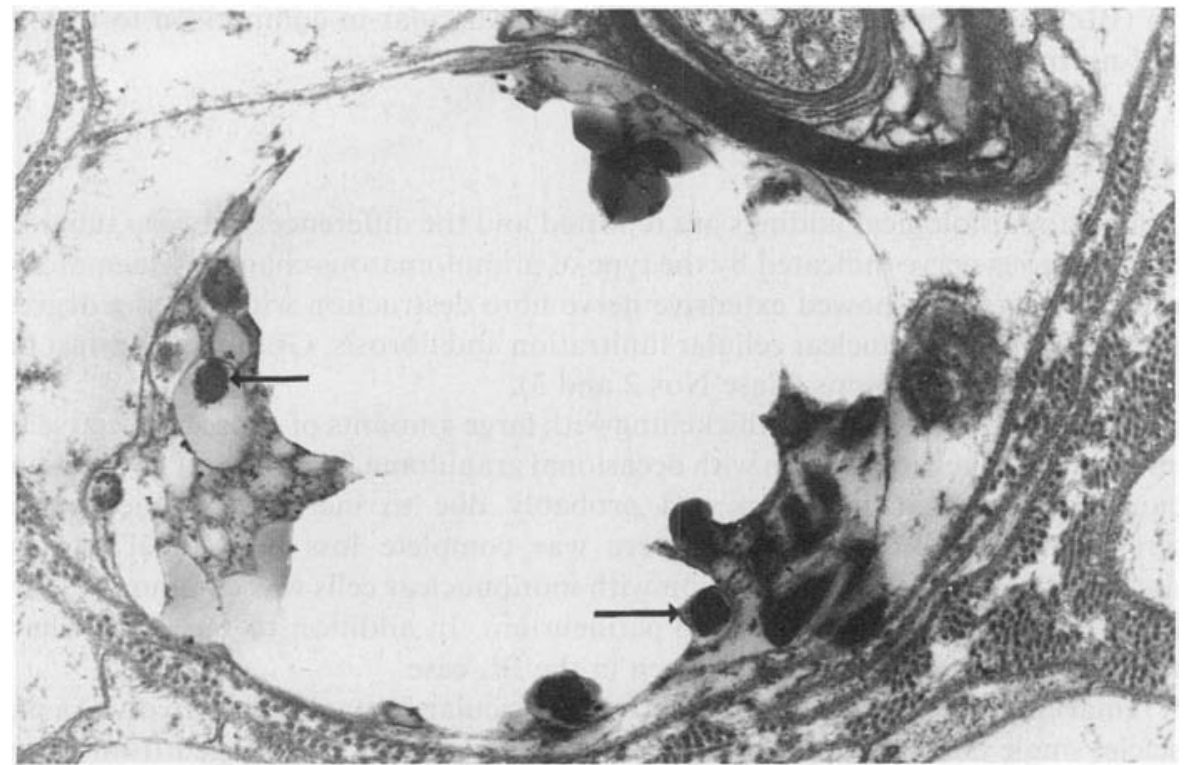

Figure 2. Posterior tibial nerve of treated BT case showing multiple bacilli (arrows) within Schwann cell. Electronmicrograph $\times 37,500$.

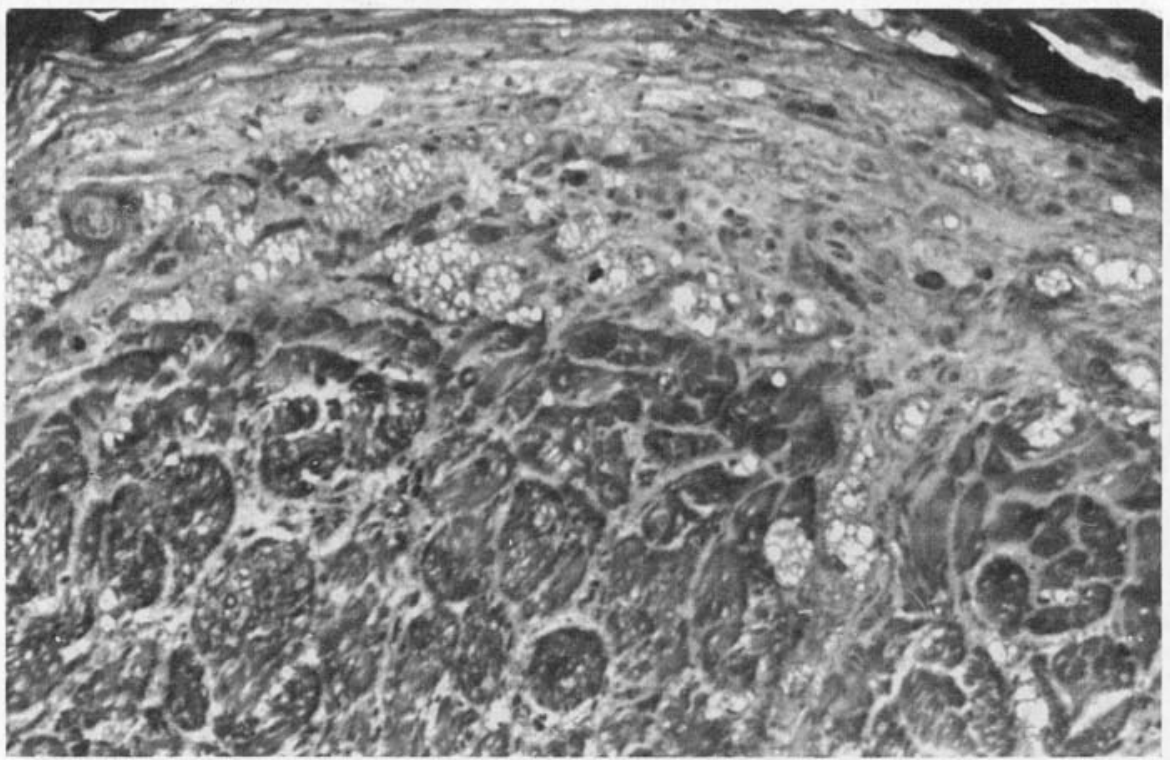

Figure 3. Posterior tibial nerve of treated BL case showing presence of foamy macrophages within perineurial and intrafascicular regions. Toluidine blue $\times 275$.

Endoneurial blood vessels were plentiful with what appeared to be connective tissue thickening and multiple layering of the basement membrane, with perivascular inflammatory cell infiltration. Increased vascularity was noted in the perineurium and epineurium. 


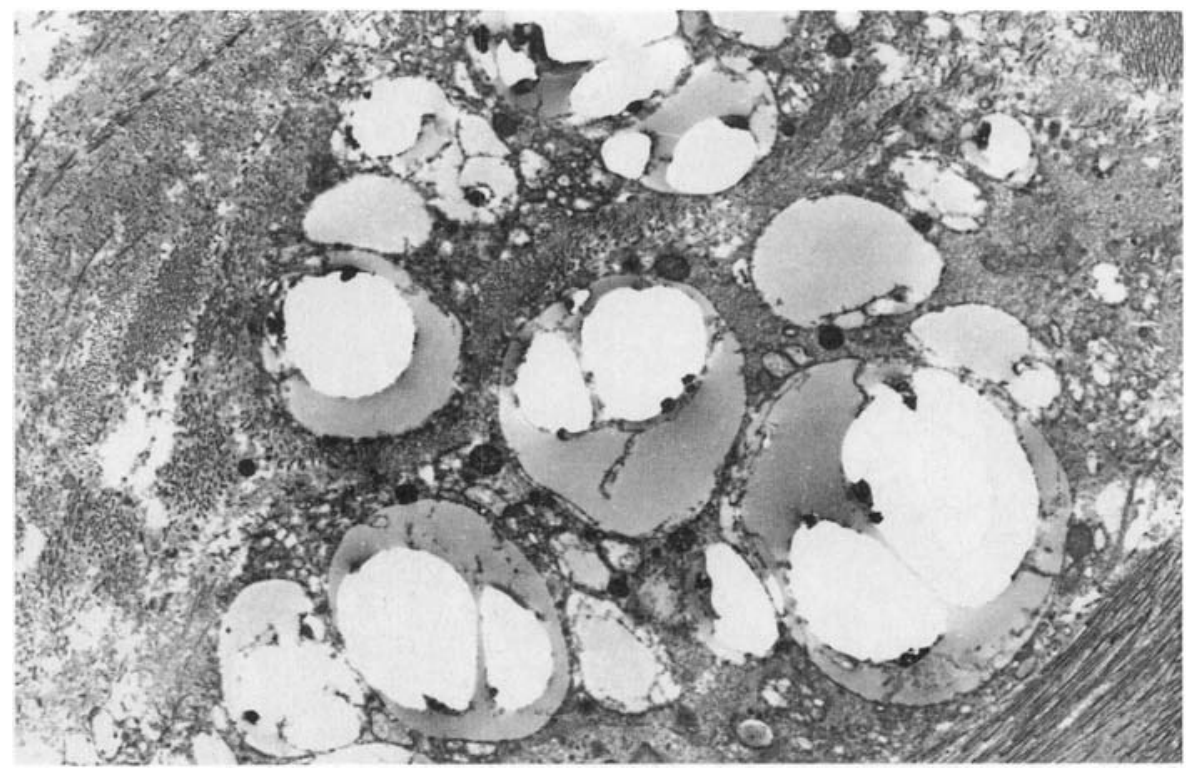

Figure 4. Posterior tibial nerve of treated BL case showing large numbers of bacilli within a macrophage, with marked endoneurial fibrosis. EM $\times 9450$.

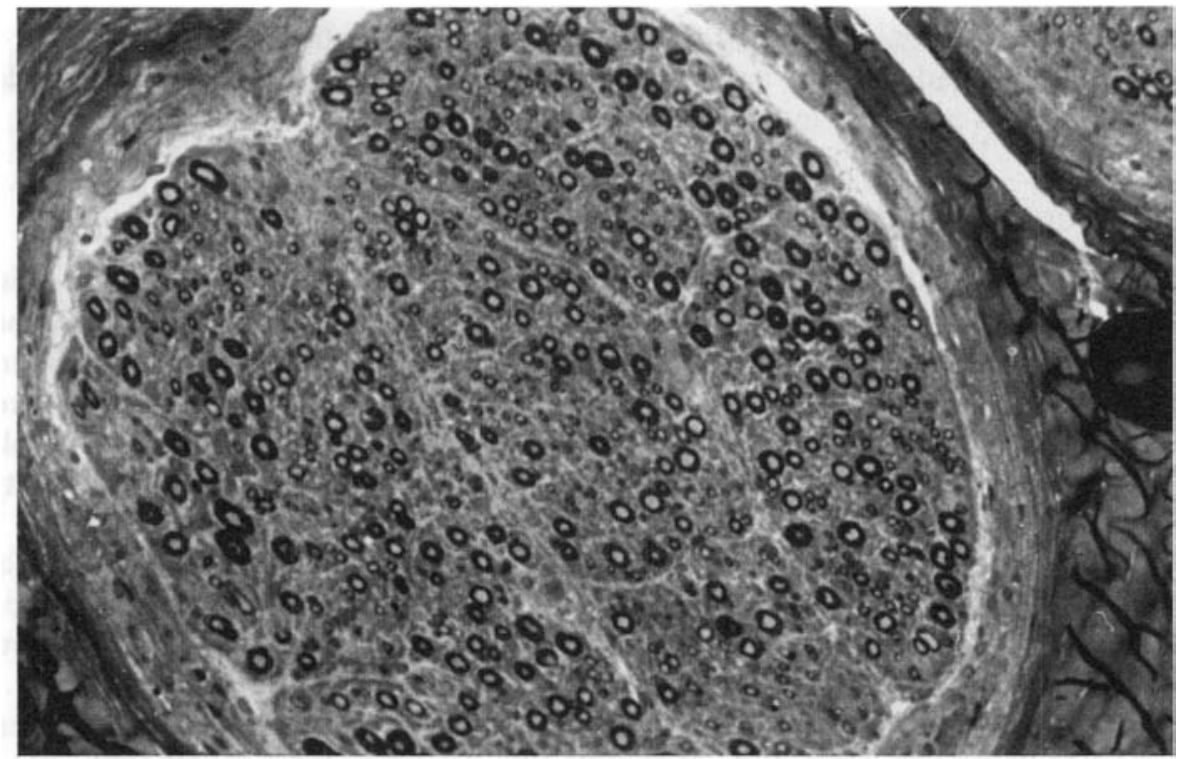

Figure 5. Median nerve of treated LL case showing large numbers of myelinated axons, endoneurial fibrosis and perineurial thickening. Toluidine blue $\times 275$.

Foamy macrophages packed with bacilli were also seen in perineurium and endoneurium of the BL case. In one LL case there was only approximately $50 \%$ myelinated fibre destruction, with the remaining fibres being arranged in groups with 


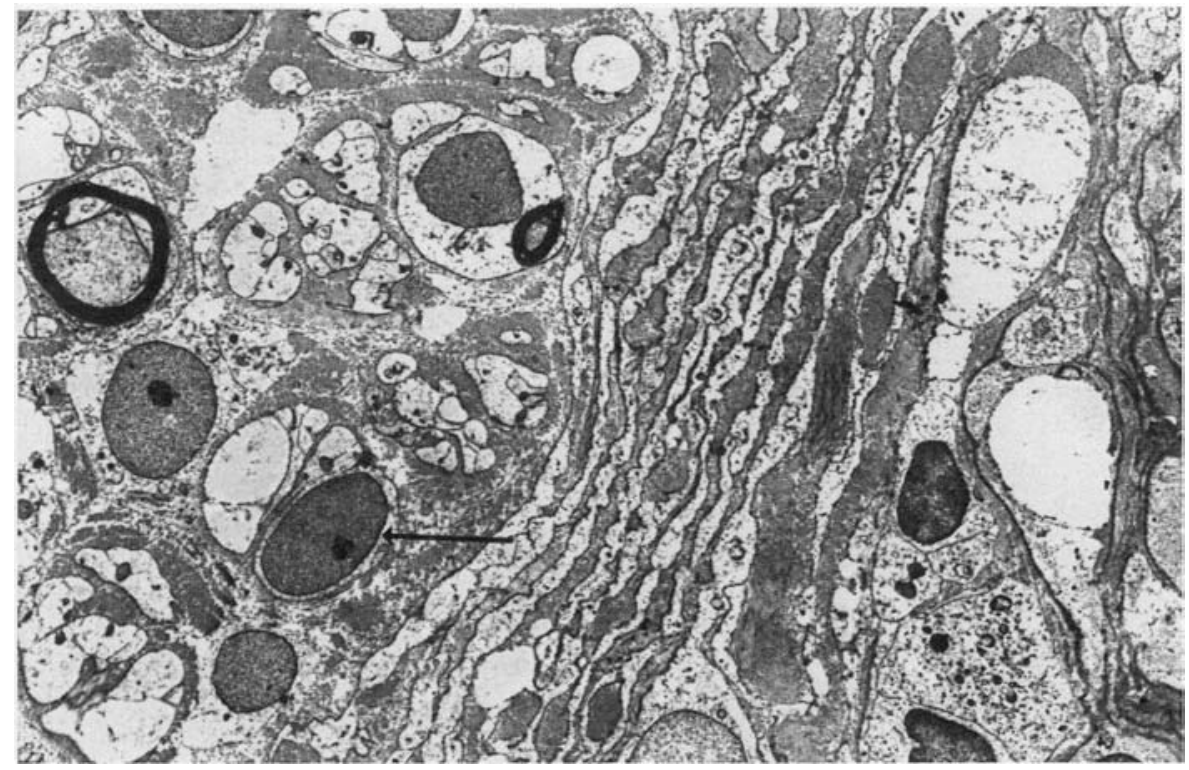

Figure 6. Posterior tibial nerve of treated LL case showing numbers of 'depleted' Schwann cells (arrow) and endoneurial fibrosis. $\mathrm{EM} \times 4800$.

greater amounts of dense connective tissue but with little inflammatory infiltrate. The other LL patient had massive amounts of interfascicular connective tissue with large numbers of axons arranged in classical regenerating units.

\section{ULTRASTRUCTURAL FINDINGS}

BT cases: Gross destruction of myelinated and unmyelinated axons as noted on 1-micron sections. A number of bacilli were seen mainly in Schwann cells (Figure 2) of myelinated and unmyelinated axons and in some macrophages. It is not possible to say whether the bacilla were alive or dead but the organisms of ten appear whole (solid). No intra-axonal bacilli were evident. Plenty of depleted Schwann cells are present with loss of cytoplasm and axons. There are also collections of mononuclear cells mainly of the epithelioid type. Occasional lymphocytes and fibroblasts (containing bacilli) were seen.

BL case: Figure 4 shows a larger number of bacilli as compared with the BT case. These were seen mainly within foamy macrophages as dark staining structures. There was gross depletion of myelinated and unmyelinated axons. Larger amounts of endoneurial collagen were seen, mainly arranged around Schwann cells.

LL case: Section showed greater degree of endoneurial fibrosis with large numbers of depleted Schwann cells (Figure 6) and virtually no inflammatory cell infiltration or granuloma formation.

\section{Discussion}

Palande ${ }^{2}$ reported the presence of $M$. leprae in the ulnar nerve of one treated BT case. 
Dastur ${ }^{3}$ reported finding $M$. leprae in the index branch of the radial cutaneous nerves in 8 LL cases treated for periods of 18 months to 6 years. This is probably the first paper to report the possible finding of bacilli in nerve trunks of BT and BL patients after prolonged drug treatment.

With one exception (see Table 1), all cases were skin smear negative and these findings would support the observations of other workers who have noted a discrepancy in the bacillary content of nerve and skin. ${ }^{4}$ Also 2 out of the 3 BT cases had a nerve bacillary index $(\mathrm{BI})>2$ indicating that these are in reality multibacillary cases. This further strengthens the view that if nerve biopsies were as easily available as skin biopsies more patients would be classed as multibacillary. ${ }^{5}$ There may be a place for reviewing the present criteria for disease activity where currently skin tissue response is thought to demonstrate general tissue response to M. leprae. $^{6}$

One-micron section and ultrastructural studies when compared with the findings of other workers ${ }^{1,3,7,8}$ did not reveal any differences apart from the fact that our specimens showed more severe, and in some, complete nerve destruction. This is not surprising because cases with localized lesions exhibiting clinically irreversible damage were selected. There were no signs of active nerve degeneration but the presence of mononuclear cell infiltration would indicate ongoing disease activity. High bacillary content and proliferation were features of Schwann cells but no bacilli were seen in axons.

Using the criteria of Dastur ${ }^{1}$ and others these bacilli will fall into the 'solid' category and therefore be considered alive. However one is not able to be sure whether these organisms are alive or dead. One can only describe the mycobacteria as appearing as 'whole'.

\section{POSSIBLE IMPLICATIONS OF FINDING BACILLI IN THE NERVES}

Bacilli may be in a physiologically dormant state or there may be a problem with drugs penetrating into nerves in sufficient concentrations to kill the organisms. The bacilli may be dead and not removed because the scavenging cells may not be getting into nerves or because the macrophages may not have adhesion molecules on their surface to cross the blood nerve barrier and remove the organisms. Finally it is possible that nerves act as a reservoir for $M$. leprae antigen.

\section{POSSIBLE ROLE IN 'RELAPSE'}

Dead bacilli can be a continuing source of antigen - releasing antigen into the systemic circulation may possibly cause damage to another nerve without any other clinical evidence of leprosy. This may explain the situation of sudden nerve involvement in a patient, years after 'cure' of the disease. ${ }^{9}$ If the organisms are alive they may cause relapse in the true sense of the word.

In conclusion it is not possible to say whether the organisms found in these nerves are alive or dead. Either way this finding merits further investigation (?mouse footpad cultures) af ter isolating the bacilli from fresh nerve specimens. It is likely that nerves act as reservoirs for bacilli and that the true histological picture as to whether the disease is multibacillary or paucibacillary may be better represented here. The value of skin smear in assessment of disease activity and criteria for deciding the duration of treatment needs to be re-examined. And finally should the current principles of management be re- 
evaluated as it would seem that $M$. leprae with its constant source of antigen cannot be eliminated from some nerves in spite of 'adequate' drug treatment?

\title{
References
}

${ }^{1}$ Dastur DK. Leprosy (An infectious and immunological disorder of the nervous system). In: Handbook of Clinical Neurology, Vol 33. Vinken PJ, Bryun GW (eds), Amsterdam: North Holland Publishing Co. 1976, 421-68.

2 Palande DD. The ulnar nerve in the lower arm in dimorphous leprosy-some observations. Lepr India, 1974; 46: (No. 3), 1-6.

${ }^{3}$ Dastur DK, Porwal GL, Shah JS, Revankar CR. Immunological implications of necrotic, cellular and vascular changes in leprous neuritis: light and electron microscopy. Lepr Rev, 1982; 53: 45-65.

${ }^{4}$ Srinivasan H, Rao KS, Iyer CGS. Discrepancy in the histopathological features of leprosy lesions in the skin and peripheral nerve. Lepr India, 1982; 54: 275-82.

${ }^{5}$ Lucas SB, Ridley DS. The use of histopathology in leprosydiagnosis and research. Lepr Rev, 1989;60:257-62.

6 Ridley DS, Ridley MJ. Classification of nerves is modified by the delayed recognition of M. leprae. Int J Lepr, 1986; 54: (No. 4), 596-606.

7 Job CK, Desikan KV. Pathological changes and their distribution in peripheral nerves in lepromatous leprosy. Int J Lepr, 1968; 36: (No. 3), 250-70.

8 Pearson JMH, Weddel AGM. Perineurial changes in untreated leprosy. Lepr Rev, 46: 51-67.

9 Job CK. Nerve damage in leprosy. Int J Lepr, 1989; 57: (No. 2), 532-9.

\section{Des mycobactéries dans les troncs nerveux des patients de lèpre traités à longue terme}

\author{
J H Pereira, D D Palande et S E Gschmeissner
}

Sommaire La présence des mycobactéries a été détectée en 4 sur 8 troncs nerveux périphériques des patients ( 3 de BT et un de BL) qui suivaient des traitements de DDS et/ou MDT pour des périodes de temps entre les 21 mois et les 8 ans. La plupart des bacilles semblaient être 'entiers'. La destruction du nerf avec des zones d'infiltration granulomateuse se montrait plus active que prévue. On discute des possibles raisons pour la persistance des bacilles dans des nerfs traités et les implications qu'elles peuvent avoir pour la 'rechute' des patients.

\section{Micobacterias en los troncos nerviosos de pacientes de lepra tratados a largo plazo}

\author{
J H Pereira, D D Palande y S E Gschmeissner
}

Resumen Se encontraron micobacterias en 4 de 8 troncos nerviosos periféricos de pacientes ( 3 de BT y l de BL) que llevaban periodos de tiempo entre los 21 meses y los 8 años bajo tratamientos de DDS y/o MDT. La mayor parte de estos bacilos parecían estar 'enteros'. El grado de destrucción del nervio con áreas de infiltración granulomatosa aparentó ser más elevado de lo previsto. Se discuten las posibles razones de la persistencia de bacilos en nervios tratados y las consecuencias que esto pueda tener para la 'recaída' de los pacientes. 